\title{
Globalization and Exchange-Rate Pass-Through in Europe: Is There a Link?
}

\author{
Antonia López-Villavicencio \\ GATE-CNRS and University Lumière Lyon 2 \\ Valérie Mignon* \\ EconomiX-CNRS, University of Paris Nanterre, and CEPII
}

\begin{abstract}
This paper assesses the impact of globalization on Exchange-Rate Pass-Through into import prices in three core eurozone countries characterized by different degrees of openness. We looked at various indicators of globalization and used data since 1983 to find evidence of a generalized link between globalization and Exchange-Rate Pass-Through. In particular, factors related to trade integration, such as an increase in the import penetration rate or lower trade tariffs, reduce the degree of Exchange-Rate Pass-Through. However, the rising prominence of China in European imports does not contribute to the decline in pass-through. Overall, our findings show that while Exchange-Rate Pass-Through is incomplete, it remains significant even when controlling for the effects of trade globalization.
\end{abstract}

JEL Classifications: E31, F31, F4, C22

Keywords: Exchange rate pass-through, Import prices, Globalization, Eurozone.

\footnotetext{
* Corresponding Author: Valérie Mignon; Professor, EconomiX-CNRS, University of Paris Nanterre, 200 avenue de la République, 92001 Nanterre Cedex, France. Phone: + 33 (0) 1409758 60. Email: valerie.mignon@parisnanterre.fr.

Co-Author: Antonia López-Villavicencio; Professor, GATE-CNRS and University Lumière Lyon 2, France. Email: lopez@gate.cnrs.fr.
} 


\section{Introduction}

The partial and declining character of Exchange-Rate Pass-Through (ERPT) into import prices has received a lot of attention in the literature. ${ }^{1}$ Various explanations have been proposed, which include (i) a macroeconomic justification (Monacelli 2005) in which the incompleteness comes from nominal rigidities leading to unresponsiveness in prices in the short run, (ii) a microeconomic explanation linking an incomplete ERPT with increasing pricing-to-market behavior of firms (Betts and Devereux 2000), and (iii) the existence of a stable monetary policy environment, where the size of pass-through is a function of the monetary policy (Taylor 2000). However, recently, López-Villavicencio and Mignon (2017) have shown that uncertainty about domestic monetary policy does not affect the pass-through to import prices. Thus, factors other than monetary ones may be at play in explaining the dynamics of ERPT to import prices. Among these, globalization appears to be of particular interest given the growing trade integration observed over the past few decades. Two effects are at play; first, globalization impacts the inflation dynamics through its influence on the degree of competition. As shown by Dornbusch (1987) and Benigno and Faia (2016), globalization as reflected in greater competition implies higher ERPT; the pass-through intensity depends on the degree of concentration in the market and on the share of foreign products in the domestic market. Secondly, globalization affects the dynamics of inflation through its impact on the pricing strategies of domestic firms selling in the home market. This channel has been studied by Gust, Leduc, and Vigfusson (2010) who state that greater competition implies lower ERPT. As a firm's pricing decisions depend on the prices set by its competitors, the optimal situation for an exporter is to vary its markup in response to shocks that change the exchange rate, thus insulating import prices from exchange rate movements.

The debate on the theoretical implications of globalization for ERPT is far from conclusive. We explore the issue in this paper by empirically investigating if trade integration affects the pass-through into import prices. Our contribution is threefold. First, there is little literature that explores the link between globalization and ERPT, especially for countries outside the US. We fill this gap by focusing on three core euro area economies, based on

${ }^{1}$ See, e.g., Knetter (1989), Campa and Goldberg (2005), and Burstein and Gopinath (2013). 
their external exposure. Specifically, we consider Belgium which presents the highest degree of trade openness among the core countries; France which is characterized by the lowest one; and Germany which is at an intermediate level corresponding to the European monetary union aggregate degree of openness (Figure 1). As import prices constitute a major transmission channel of changes in the euro to domestic prices and, in turn, inflation and output, analyzing ERPT is critical in the context of a monetary union. The same exchange-rate change may affect eurozone countries differently, depending on their external exposure. Accounting for such different responses of import prices to euro exchange-rate changes is important for the conduct of the single monetary policy. Second, to provide a complete and robust picture, we use various indicators of globalization such as (i) an increase in the degree of trade openness, (ii) a higher presence of Chinese imports in total imports ${ }^{2}$, and (iii) lower import tariffs. Third, with regard to the literature for the euro area $^{3}$, we overcome the drawback of short time-period samples used in these previous studies by considering a longer time period.

By using quarterly data over the 1983Q1 2016Q2 period, we show that incomplete ERPT is a general result in the sense that exchange-rate changes are not fully reflected in import prices. Furthermore, interacting exchangerate changes with globalization indicators reveals a generalized link between openness and ERPT. Indeed, an increase in (i) the degree of import penetration and (ii) a decline in import tariffs contribute to explaining the incomplete ERPT into import prices. However, we show that an increase in China's share of European imports has not induced a competitive response in the exporters of other countries so as to induce them to absorb exchange-rate depreciations.

The rest of the paper is organized as follows. Section 2 briefly describes our methodology. Section 3 presents the data and some stylized facts. Section 4 displays our estimation results, and Section 5 concludes the paper.

\footnotetext{
${ }^{2}$ This indicator based on China is used by Marazzi, Sheets, Vigfusson, Faust, Gagnon, Marquez, Martin, Reeve, and Rogers (2005) who show that booming Chinese exports to the United States help explain the low ERPT value in the U.S.

${ }^{3}$ See, e.g., Schroder and Hufner (2002); Anderton (2003); Hahn (2003); Campa, Goldberg, and González-Mínguez (2005); Campa and González-Mínguez (2006); Faruqee (2006); and Ben Cheikh and Rault (2016).
} 


\section{Methodology}

In existing literature, the ERPT is modeled by considering variations of the following equation:

$$
\Delta m p_{t}=\alpha+\sum_{j=1}^{n} \gamma_{j} \Delta m p_{t-j}+\rho \Delta y_{t}+\lambda \Delta m c_{t}^{*}+\theta \Delta e_{t}+\epsilon_{t}
$$

where $m p$ represents import prices, $y$ is a local demand factor, $m c^{*}$ stands for the exporter marginal cost (i.e., the foreign production costs), $e$ is the nominal effective exchange rate, and $t$ refers to the period. All the variables are expressed in logarithms. Our primary concern in this equation is the passthrough elasticity which corresponds to the coefficient for the exchange-rate change, namely $\theta$. The case of $\theta=1$ refers to a complete ERPT, corresponding to one-for-one pass-through changes in import prices. Incomplete ERPT occurs when $\theta<1$, i.e., when exporters adjust their markup.

To explore the global factors' dimension of pass-through, our empirical strategy extends the benchmark ERPT equation as follows:

$$
\Delta m p_{t}=\alpha+\sum_{j=1}^{n} \gamma_{j} \Delta m p_{t-j}+\rho \Delta y_{t}+\lambda \Delta m p_{t}^{*}+\theta \Delta e_{t}+\theta^{c}\left(\Delta e_{t} C_{t}\right)+\delta C_{t}+\epsilon_{t}
$$

where $C$ is an indicator of trade integration: changes in the import penetration rate, changes in trade tariffs for a country's imports and changes in the weight of China in a country's imports. In Equation (2), we interpret a significant coefficient $\theta^{C}$ as evidence of ERPT being affected by global factors. 


\section{Data}

\section{A. Sample and variables}

As previously mentioned, we consider three core eurozone countries, namely Belgium, Germany, and France, over the period 1983Q1 to 2016Q2.

Regarding the measure of import prices, although most of the existing studies at the aggregate level use import unit value indexes, we use the import price deflator extracted from the Organisation for Economic Co-operation and Development (OECD) database. This choice allows us to overcome some important drawbacks associated with import unit values, namely: (i) they are biased in case of changes in the bundle of goods, (ii) they present some volatility owing to frequent quantity adjustments that may modify the indexes without any change in prices, and, (iii) they encounter important measurement errors, making them imperfect proxies for trade prices at the country level (Knetter 1989, Takagi and Yoshida 2001). Import prices are free of these biases. ${ }^{4}$ They measure actual transaction prices of imported goods and allow researchers to account for (i) changes in the composition of the bundle of imported goods of the country under consideration, (ii) the price determinants of goods (quantity of units sold, change in quality, guarantee conditions, etc.), and (iii) price fluctuations and variations in the demand for comparable competitive goods over time.

Turning to the variables on the right-hand side of Equation (1), both marginal costs and importer's demand characteristics are highly difficult to evaluate since they are not directly observable. This explains the use of proxies in the literature. In our specification, following Marazzi, Sheets, Vigfusson, Faust, Gagnon, Marquez, Martin, Reeve, and Rogers (2005) and Marazzi and Sheets (2007), we use the aggregated OECD foreign Producer Price Index (PPI) as the proxy for production costs. For the local demand factor, we use the Gross Domestic Product (GDP) as is common in the literature (Campa, Goldberg, and González-Mínguez 2005). The exchange rate corresponds to the nominal effective exchange rate provided by the Bank of International Settlements (BIS), with an increase in the index indicating a depreciation.

${ }^{4}$ See, e.g., Marazzi and Sheets (2007) and de Bandt and Razafindrabe (2014). 
We now describe our indicators of globalization. First, to capture the number of foreign products in each destination market, we consider the import penetration ratio rate, i.e., the participation of foreign firms in the domestic economy, measured by the share of imports in GDP. Overall trade values are collected from the International Monetary Fund (IMF) International Financial Statistics (IFS) database. Note that according to our previous discussion (Section 1), the sign of the ERPT coefficient can be positive or negative. Indeed, following Benigno and Faia (2016), $\theta^{C}$ should be positive and significant if we expect that higher trade openness will mean that there are more foreign firms competing in the destination market. In this case, globalization affects the dynamics of imported inflation through its effect on ERPT into import prices and the rise in the share of foreign products in the domestic market, increasing the pass-through degree. However, in the case of strategic complementarity in setting prices, an exporter does not want its price to deviate too much from that of its competitors. Thus, the exporter's price becomes more responsive to the prices of its competitors as its markup increases. Hence, it is optimal for a firm to vary its markup more and its price less in response to an exchange-rate change. Accordingly, we should observe a reduction of the pass-through of exchange-rate changes into import prices with higher trade integration ( $\theta^{C}$ should be negative and significant).

Second, we also evaluate how China's presence in total imports affects the pricing decisions of exporters from other countries. The underlying reasoning is that increasing import penetration of China induces changes in the competitive environment and forces exporters to lower markups in response to an exchange-rate depreciation (Bergin and Feenstra 2009). Therefore, we take into account China's import share in total imports (Marazzi, Sheets, Vigfusson, Faust, Gagnon, Marquez, Martin, Reeve, and Rogers 2005).

A third measure of globalization is based on trade tariffs. Although tariffs represent only a fraction of overall trade costs, they remain an important underlying factor in greater trade integration. In this respect, Gust, Leduc, and Vigfusson (2010) argue that with lower costs, exporters should reduce their prices and the home country's import share should rise. Since foreign exporters' prices fall relative to that of their competitors (i.e., the domestic firms), they will be able to increase their markups and still gain a market share. Conversely, the prices for domestic goods rise relative to those of their competitors, and domestic firms are forced to cut their markups in reaction 
to stiffer competition from abroad. With higher markups on foreign goods, strategic complementarity intensifies and foreign exporters become more willing to vary their markups in response to cost shocks. Thus, according to Gust, Leduc, and Vigfusson (2010), a decline in trade costs should cause a fall in the pass-through (i.e., $\theta^{C}$ should be positive). Alternatively, we could argue that exporters who are subject to high tariff rates will face more local competition in the markets to which they export and hence will be more constrained in passing exchange-rate changes onto the prices that they charge. Data on import tariff rates for the European Union are taken from the United Nations Conference on Trade and Development (UNCTAD) Trade Analysis Information System (TRAINS). Data are annual and correspond to the average of ad-valorem duties. ${ }^{5}$

\section{B. Descriptive statistics}

Table 1 provides some descriptive statistics for our three different globalization indicators and their growth over the study period. As can be seen, Belgium is the country displaying the highest degree of trade openness as measured by the import penetration rate, followed by Germany and France, with Germany being very close to the average European Monetary Unit level (Figure 1 for the year 2015). However, the level of trade exposure shows an upward trend everywhere, particularly in France and Germany.

${ }^{5}$ We use the applied tariff which corresponds to the tariff actually charged on an import. 


\section{Figure 1. Degree of openness to trade in 2015}

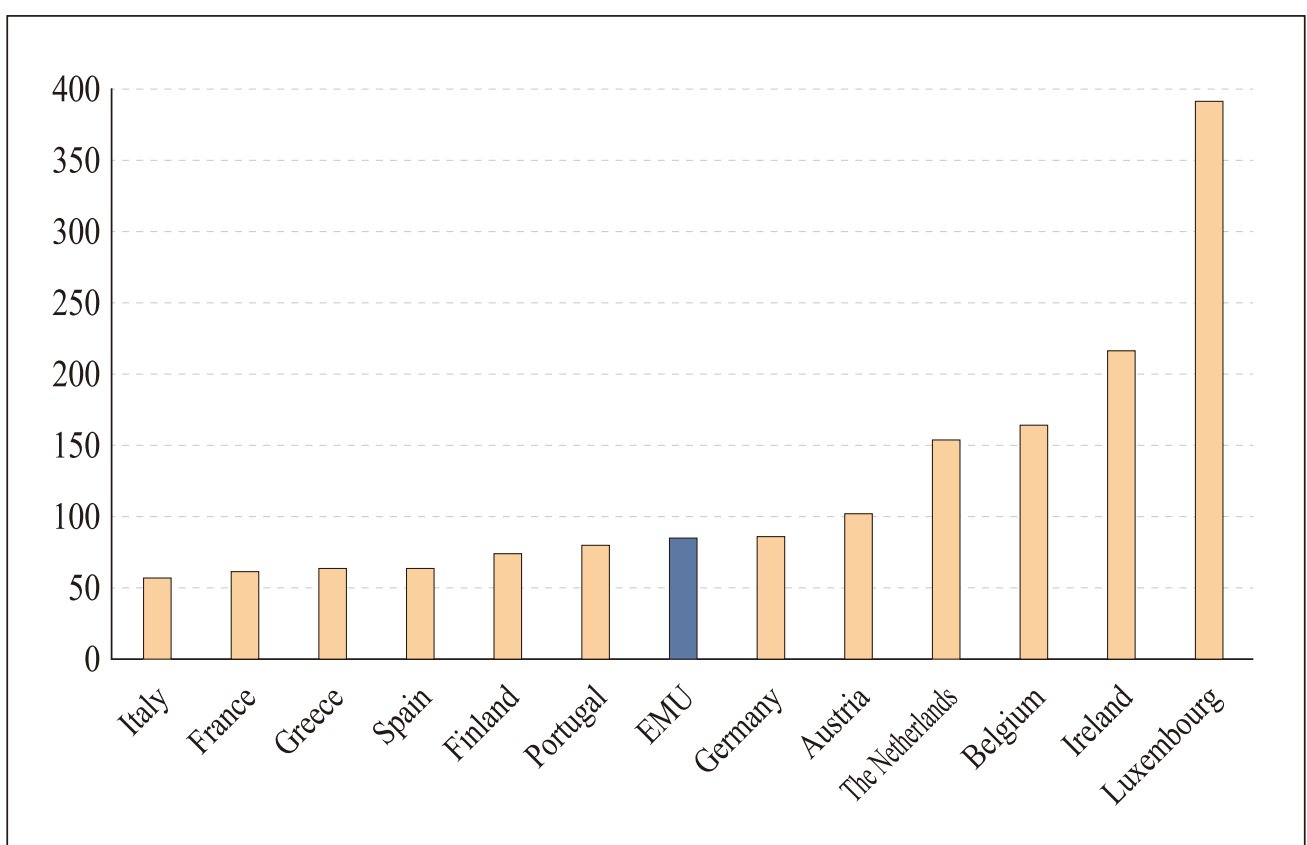

(Note) Trade is the sum of exports and imports of goods and services measured as a share of gross domestic product. Data source: World Bank.

Table 1. Descriptive statistics on globalization

\begin{tabular}{|c|c|c|c|c|c|c|}
\hline \multirow{2}{*}{ Country } & \multicolumn{2}{|c|}{$\begin{array}{c}\text { Import penetration } \\
\text { rate }\end{array}$} & \multicolumn{2}{c|}{ China's share } & \multicolumn{2}{c|}{ Tariffs } \\
\cline { 2 - 7 } & Level & Growth & Level & Growth & Level & Growth \\
\hline Belgium & 0.692 & 0.469 & 0.025 & 5.591 & 2.183 & -2.972 \\
\hline France & 0.250 & 1.124 & 0.046 & 8.581 & 2.183 & -2.972 \\
\hline Germany & 0.299 & 1.012 & 0.048 & 7.959 & 2.183 & -2.972 \\
\hline
\end{tabular}

(Note) This table reports the average values of globalization indicators over the study period. 


\section{Results}

\section{A. Estimated ERPT}

We will first look at the estimation of our baseline Equation (1). The corresponding results are presented in Table 2. As shown, an incomplete ERPT is the general result, which confirms the findings in the literature. ${ }^{6}$ The pass-through estimates present the expected positive sign: an increase in the nominal exchange rate translates into a depreciation of the currency and should typically be followed by a rise in prices. Our results show that a $1 \%$ increase in the rate of depreciation of the euro raises import prices by $0.34 \%$ in Belgium, $0.32 \%$ in France, and $0.39 \%$ in Germany. For the sake of completeness, Table 2 also displays the results of the estimation of Equation (1) when a dummy variable for the introduction of the euro is included. ${ }^{7}$ As can be seen, although the estimated ERPT coefficients show a slight increase, they remain far below unity, indicating that the adoption of the single currency did not have a strong effect on the pass-through.

To assess the pass-through evolution through time, we look at Figure 2, which displays the rolling ERPT coefficients for the three countries over the period under consideration. As shown, despite the upward trend observed for the last windows - i.e., for estimation periods containing observations for the Great Recession-our findings confirm those found in the literature (references in Section 1), as ERPT steadily declines for the three countries over a long period of time.

On the whole, although our results do not provide evidence of a clearcut relationship between the degree of external exposure and the level of the pass-through, they suggest the existence of a possible positive link between the two variables.

${ }^{6}$ See Menon (1995) and Engel (2002) for a survey, and Campa and Goldberg (2005), Marazzi and Sheets (2007), Bouakez and Rebei (2008) or Gust, Leduc, and Vigfusson (2010) for more recent empirical studies.

${ }^{7}$ Specifically, Equation (1) is written as follows:

$$
\Delta m p_{t}=\alpha+\sum_{j=1}^{n} \gamma_{j} \Delta m p_{t-j}+\rho \Delta y_{t}+\lambda \Delta m c_{t}^{*}+\theta \Delta e_{t}+\delta D U M_{t}+\epsilon_{t}
$$

where $\mathrm{DUM}_{\mathrm{t}}$ is the dummy variable that takes the value 1 for introduction of the euro, and zero otherwise. 


\section{Table 2. ERPT coefficients}

\begin{tabular}{|r|c|c|}
\hline & Coefficient $(\boldsymbol{t}$-stat) & Coefficient $(\boldsymbol{t}$-stat) \\
\hline Belgium $\theta$ & $0.338(4.41)$ & $0.413(5.70)$ \\
\hline Dummy euro & $\ldots$ & $1.732(4.73)$ \\
\hline France $\theta$ & $0.316(5.99)$ & $0.353(4.48)$ \\
\hline Dermany $\theta$ & & $1.248(2.03)$ \\
\hline Dummy euro & $0.393(5.63)$ & $0.431(10.31)$ \\
\hline
\end{tabular}

(Notes) (i) This table reports the estimated ERPT coefficients from Equation (1)

(ii) Corresponding $t$-statistics are given in parentheses

(iii) Dummy euro is a variable that takes the value of 1 for introduction of the euro, and zero otherwise.

\section{B. Accounting for globalization}

To assess the role of globalization, Table 3 reports the estimation results of Equation (2). We consider the three aforementioned indicators in favor of globalization, namely: (i) an increase in the degree of import penetration, (ii) a higher presence of Chinese imports in total imports and, (iii) lower import tariffs. As can be seen, the estimate of the interaction variable $\left(\theta^{C}\right)$ is significant at conventional levels for all models except the one for the share of Chinese imports in total imports, providing clear evidence that global factors cause a structural change in ERPT. In other words, (i) an increase in the degree of import penetration and (ii) a decline in import tariffs contributed to explaining the incomplete ERPT into import prices.

On the contrary, with $\theta^{C}$ being non-significant at conventional levels, we do not find compelling evidence that an increase in China's market share is associated with lower ERPT. Following Marazzi and Sheets (2007), we find two main explanations at play here: (i) the effects of direct competition with China, making exporters from other countries hesitant to shift their dollar prices in response to fluctuations in their exchange rates, and (ii) the threat of potential competition from Chinese firms. Our findings show that, contrary to the U.S., the pass-through effect of China's growing presence in European markets is weak, i.e., it has not induced other exporters to pass-through 
exchange rates shocks.

\section{Figure 2. ERPT, rolling coefficients}

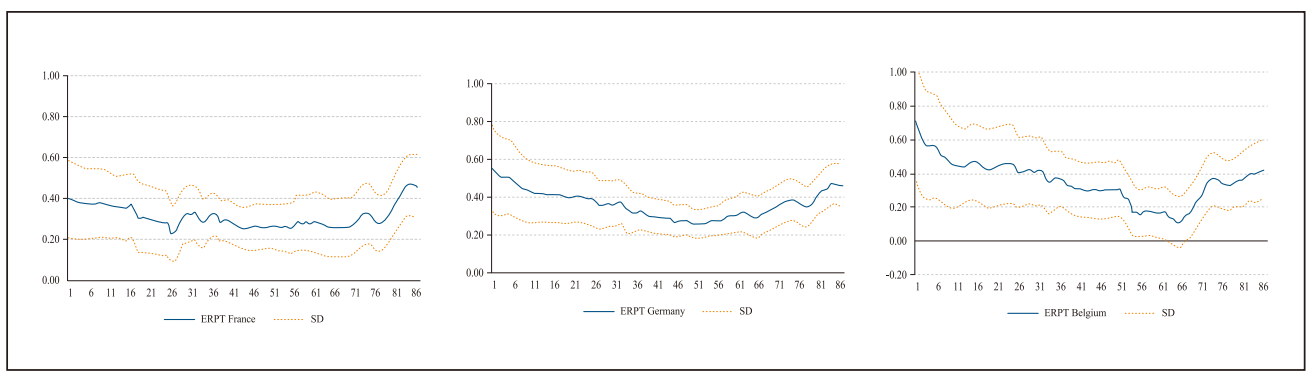

(Note) This figure reports the ERPT coefficients estimated using rolling regressions based on Equation (1).

Table 3. ERPT and global factors

\begin{tabular}{|c|c|c|c|c|}
\hline \multicolumn{2}{|c|}{} & $\begin{array}{c}\text { Import penetration } \\
\text { rate }\end{array}$ & $\begin{array}{c}\text { China's imports } \\
\text { share }\end{array}$ & Trade tariffs \\
\cline { 2 - 5 } & & Coefficient $(t$-stat) & Coefficient $(t$-stat) & Coefficient $(t$-stat) \\
\hline \multirow{3}{*}{ Belgium } & $\theta$ & $0.303(3.49)$ & $0.395(4.57)$ & $0.431(5.25)$ \\
\cline { 2 - 5 } & $\theta^{C}$ & $-0.041(-3.27)$ & $0.013(0.66)$ & $0.330(3.86)$ \\
\hline \multirow{3}{*}{ France } & $\theta$ & $0.295(6.60)$ & $0.371(5.82)$ & $0.385(6.52)$ \\
\cline { 2 - 5 } & $\theta^{C}$ & $-0.088(-3.45)$ & $-0.006(-0.31)$ & $0.147(2.66)$ \\
\hline \multirow{3}{*}{ Germany } & $\theta$ & $0.350(8.25)$ & $0.487(5.38)$ & $0.378(9.07)$ \\
\cline { 2 - 5 } & $\theta^{C}$ & $-0.035(-3.08)$ & $-0.004(-0.44)$ & $0.132(2.67)$ \\
\hline
\end{tabular}

(Notes) (i) This table reports the estimated ERPT coefficients from Equation (2).

(ii) Corresponding $t$-statistics are given in parentheses.

\section{Conclusion}

This paper analyzes the impact of globalization on ERPT into import prices for three core eurozone countries, namely Belgium, France and Germany, which are characterized by various degrees of openness. With protectionism on the rise, this question is worth exploring.

Our empirical findings show that globalization explains part of the 
decaying character of ERPT. Indeed, a rise in the share of imports in GDP, i.e., an increase in the import penetration rate, as well as tariff cuts contributes to explain the incomplete ERPT in our sample of countries. However, we show that ERPT incompleteness cannot be related to China's gains in market shares. Overall, even after accounting for the effects of globalization, ERPT into import prices remains significant highlighting that exchange-rate changes do impact domestic prices.

Received 6 October 2018, Revised 30 October 2018, Accepted 2 November 2018

\section{References}

Anderton, R. "Extra-euro area manufacturing import prices and exchange rate pass-through.” Working Paper Series 0219, European Central Bank, 2003.

Ben Cheikh, N., and C. Rault "Recent estimates of exchange rate pass-through to import prices in the euro area." Review of World Economics (Weltwirtschaftliches Archiv) 152(1) (2016): 69-105.

Benigno, P., and E. Faia "Globalization, Pass-Through, and Inflation Dynamics." International Journal of Central Banking 12(4) (2016): 263-306.

Bergin, P. R., and R. C. Feenstra "Pass-Through of Exchange Rates and Competition between Floaters and Fixers." Journal of Money, Credit and Banking 41(s1) (2009): 35-70.

Betts, C., and M. B. Devereux "Exchange rate dynamics in a model of pricingto-market." Journal of International Economics 50(1) (2000): 215-244.

Bouakez, H., and N. Rebei "Has exchange rate pass-through really declined? Evidence from Canada." Journal of International Economics 75(2) (2008):249267. 
Burstein, A., and G. Gopinath. "International Prices and Exchange Rates." NBER Working Papers 18829, National Bureau of Economic Research, Inc., 2013.

Campa, J., and L. Goldberg. "Exchange Rate Pass-Through into Import Prices," The Review of Economics and Statistics 87(4) (2005): 679-690.

Campa, J., and J. M. Gonzalez-Mínguez. "Differences in exchange rate passthrough in the euro area." European Economic Review 50(1) (2006): 121-145.

Campa, J. M., L. S. Goldberg, and J. M. Gonzalez-Mínguez "Exchange-Rate Pass-Through to Import Prices in the Euro Area." Working Paper 11632, National Bureau of Economic Research, 2005.

de Bandt, O., and T. Razafindrabe. "Exchange Rate pass-through to import prices in the Euro area: A multi-currency investigation." International Economics 138 (2014): 63-77.

Dornbusch, R. "Exchange Rates and Prices.” American Economic Review 77(1) (1987): 93-106.

Engel, C. "The responsiveness of consumer prices to exchange rates and the implications for exchange rate policy: a survey of a few recent new-openeconomy models.” Working Paper No. 8725, NBER, 2002.

Faruqee, H. "Exchange Rate Pass-Through in the Euro Area." IMF Staff Papers 53(1) (2006): 63-88.

Gust, C., S. Leduc, and R. Vigfusson ."Trade integration, competition, and the decline in exchange-rate pass-through." Journal of Monetary Economics 57(3) (2010): $309-324$.

Hahn, E. "Pass-through of external shocks to euro area inflation." Working Paper Series 0243, European Central Bank, 2003. 
Knetter, M. M. "Price Discrimination by U.S. and German Exporters." American Economic Review 79(1) (1989): 198-210.

Lopez-Villavicencio, A., and V. Mignon "Exchange rate pass-through in emerging countries: Do the inflation environment, monetary policy regime and central bank behavior matter?" Journal of International Money and Finance 79(C) (2017): 20-38.

Marazzi, M., and N. Sheets "Declining exchange rate pass-through to U.S. import prices: The potential role of global factors." Journal of International Money and Finance 26(6) (2007): 924 - 947.

Marazzi, M., N. Sheets, R. Vigfusson, J. Faust, J. Gagnon, J. R. Marquez, R. Martin, T. A. Reeve, and J. Rogers. "Exchange rate pass-through to U.S. import prices: some new evidence," International Finance Discussion Papers 833, Board of Governors of the Federal Reserve System (U.S.), 2005.

Menon, J. "Exchange rate pass-through." Journal of Economic Surveys 9(2) (1995): 197-231.

Monacelli, T. "Monetary Policy in a Low Pass-through Environment." Journal of Money, Credit and Banking 37(6) (2005): 1047-1066.

Schroder, M., and F. P. Hufner "Exchange rate pass-through to consumer prices: a European perspective," ZEW Discussion Papers 02 20, ZEW, Center for European Economic Research, 2002.

Takagi, B. S., and Y. Yoshida "Exchange Rate Movements and Tradable Goods Prices in East Asia: An Analysis Based on Japanese Customs Data, 19881999," IMF Staff Papers 48(2) (2001): 266-289.

Taylor, J. B. "Low inflation, pass-through, and the pricing power of firms." European Economic Review 44(7) (2000): 1389-1408. 